\title{
NEIBA
}

\section{The Metaphor of "War on Drugs" and "Mass Murder" in the Philippines: discourse analysis, power relations, and an interview with President Rodrigo Duterte} Gabriel Gama de Oliveira Brasilino

Vínculo Institucional: Pontifícia Universidade Católica do Rio de Janeiro (PUC)

\section{Resumo:}

A proposta desse artigo é oferecer uma análise das declarações proferidas pelo atual presidente das Filipinas, Rodrigo Duterte, numa entrevista produzida pelo Al Jazeera. Duterte foi eleito a partir de uma campanha focada na retórica das 'drogas', crimes e combate à corrupção, um discurso político insistente na metáfora da guerra às drogas. Duterte tentou legitimar os assassinatos extralegais de mais de 3.500 cidadãos, construindo "viciados" e "traficantes de drogas" como ameaças, inimigos a serem combatidos. Seguindo a Análise do Discurso de Michel Foucault (1971), argumenta-se que, embora a guerra às drogas seja uma metáfora mobilizada dentro de uma estratégia discursiva eleitoral e política, ela também pode ser interpretada como uma política de (in)segurança que produz perseguições. Delineia-se o contexto eleitoral e o nível histórico dessa "guerra às drogas" nas Filipinas, considerando, por fim, possíveis estratégias discursivas no debate sobre Segurança Pública e políticas de (des)criminalização das drogas.

Palavras-chaves:

Guerra às Drogas; Discursos de Segurança; Execuções Extralegais.

\section{Abstract ${ }^{1}$ :}

This article offers an analysis of statements pronounced by Rodrigo Duterte in an interview produced by Al Jazeera. It shows how Duterte tried to legitimize the extrajudicial killing of more than 3.500 citizens through these

\footnotetext{
${ }^{1}$ AL JAZEERA, 2016. "Mass Murder" is an expression used by Duterte in the interview, as will be shown, referring to the extrajudicial killings committed by police, the PDEA, and "vigilantes" in the context of Duterte's war on drugs. The transcription of the interview is under my responsibility.
} 


\section{NEIBA}

statements and rhetoric, a discourse dependent and effective through the metaphor of war on drugs, constructing drug dealers and users as threats, enemies to be "legitimately" killed. Drawing on Foucault's Discourse Analysis (1971), it argues that although war on drugs is a metaphor, and not war in the literal or modern sense, it is mobilized within a discursive strategy previous to, during, and after presidential elections; it is a juridicalpolitical discourse on drugs and security that results in confrontations, hunting, punishment, and, in the limit, the exclusion or extermination of declared enemies. It also delineates the electoral context and the historical level of analysis, discussing the role of discourse analysis for critical security studies.

\section{Keywords:}

war on drugs; security discourses; extrajudicial killing. 


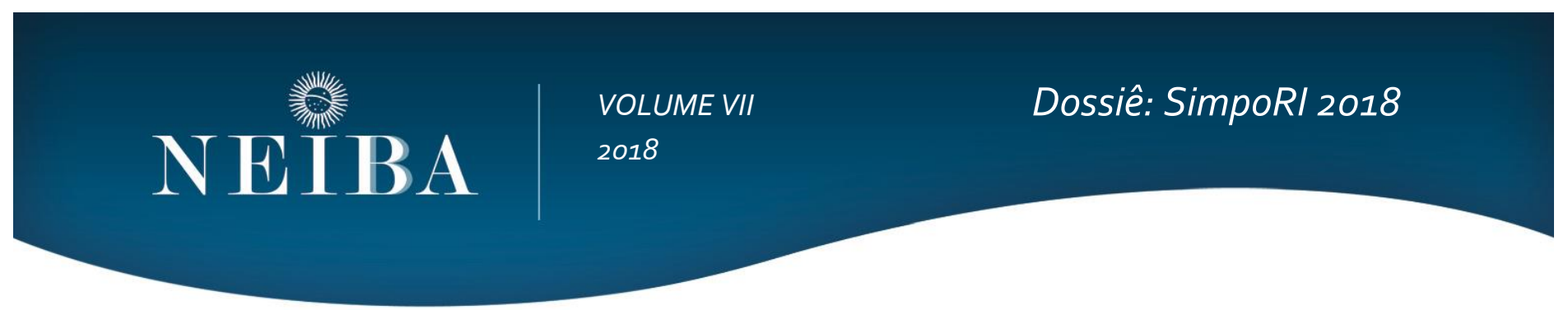

\section{Introduction}

This text offers an analysis of statements pronounced by Rodrigo Duterte, current president of the Philippines, in an interview conducted by two journalists of the Al Jazeera Media Network. Through these statements; the rhetoric of drugs, addiction, crimes, and punishment; a political discourse deeply dependent on and effective through the metaphor of war on drugs, Duterte attempted to legitimize the extrajudicial killing of thousands of people in a short period of time. In this sense, it is argued, although the war on drugs is a metaphor, "a figure of style, a technique or procedure of language" (DERRIDA, 1997, p. 276), mobilized within a discursive strategy prior to, during, and after presidential elections - the rhetoric of drugs, crimes, and justice - to maintain and expand a set of power relations and positions (i.e. presidency), it is also a biopolitics of drugs and (in)securitythat results in confrontation, hunting, punishment, and, in the limit, extermination, of declared enemies (FOUCAULT, 1971; FIGUEIREDO et al., 1997; ZACCONE, 2015). Through the metaphorical language of war,President Duterte admits and tries to legitimize and normalize exceptional (political) violence(s)in public security politics, to deal with the problem ofdrugs (AL JAZEERA, 2016).

In the following sections, this article draws on Foucault's critical discourse analysis and set the epistemological ground from which the argument follows; it delineates the context in which the interview goes, and the historical level in which elections took place in the Philippines, in Duterte's interpretation:the context of "a widespread and dimensional problem" related todrug addiction and crime (AL JAZEERA, 2016); then it explains why Duterte'swar on drugs is not war in the literal or modernwestern sense, but a metaphor mobilized in electoral and political discursive strategies, producing specific powerand knowledge-effects; it alsoanalyzes Duterte's political discourse, especially his rhetorical strategies on drugs, addiction, and crimes, in great part dependent on and effective through the metaphor of war on drugs; finally, in the conclusion, this article brings a reflexive account of previous arguments, offering directions for researchon drugs, criminal justice systems, and international political violence(s).

\section{Analysis}

Language, Foucault, and Critical Discourse

Critical discourse analysis (CDA), as with other discourse analysis methods, involves a theory of language, its nature (what it is), its effects (what it does) and how it does what it does, how it (re)producesspecific effects (i.e. identification; differentiation; subjectivation; persuasion; legitimization; normalization). CDA is interdisciplinary, however, encompassing different methods and analytical categories. This interdisciplinarity will help in a great extend here, for war on drugs, and (in)security more generally, are strongly disputed categories across disciplines in the human sciences. CDA also involves an engagement with social movements that are critical to the uneven distribution of material and symbolic resources; to the naturalization of discursive tactics - drug prohibition and war on drugs for instance - that serves powerful interests and tries to normalize militarization of security politics. The main goal of CDA, thus, is to unveil, to unmask power struggles, to show how those interests represent specific groups, despite of being presented as 'national(ist)', 'universal', 'morally correct' and 'legitimate'. In what follows, this articledraws onepistemological principles developed in Foucault'scritical and genealogical discourse analysis ${ }^{2}$.

Foucault (1971) was not interested in the internal structure of language, but in the historical level, or context, in which it is used, the rules that constitute any linguistic performance, emphasizing the excesses, abuses, and

\footnotetext{
2 On the interdisciplinarity in CDA see for example STROM, M.; ALCOCK, E. (2017); JULIOS-COSTA, M. (2015); BREEN, M. D. (2017). On Foucault's epistemology see SCHRIFT, A. (2006); SHERRATT, Y. (2005); FOUCAULT, M. (1994).
} 


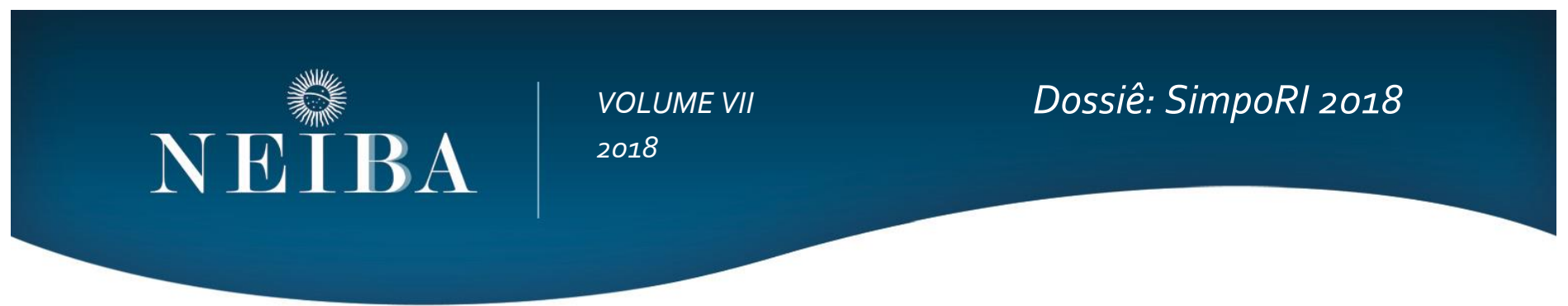

discontinuities in those rules 3 . Discourse, in this sense, "is not a language or a text but a historically, socially, and institutionally specific structure of statements, terms, categories, and beliefs" (SCOTT, 1988, p. 35). As Foucault argues, there is a fundamental relationship between what is said - words; statements; speeches - and the order of things, the social order where the conditions of possibility for those statements to be made - and contested - are distributed, allocated, dispersed. Meaning, thus, does not follow a priori words, concepts, categories, and statements, but power/knowledge relations, interactions mediated by institutions like the family, the school, the hospital, the prison, and the systems of knowledge that constitute them (i.e. medicine; pedagogy; psychiatry; law, etc.).

The point is not to ask: "What does the discourse say?" argues Foucault (1971), but

"to comprehend the statement in the narrowness and singularity of its event; to determine the conditions for its existence; to fix its limits in the narrowest way; to establish its correlations with other statements to which it may be linked; to show what other forms of enunciation it excludes" (FOUCAULT, 1971, p. 39).

So, how, under which conditions did the discourse onthe war on drugs" become dominant in the Philippines? What are the singularities of its articulation in Duterte's statements in an interview globally distributed by Al Jazeera? How is it possible that certain groups demand prohibition and (extrajudicial) punishment, while others ask for State regulation of the market, provision of health care and harm reduction?

\section{The Level of Analysis}

\footnotetext{
3 Translations from this book are under my responsibility.
}

In June 2016 Rodrigo Duterte was elected president of the Republic of Philippines, an archipelago in Southeast Asia, after an electoral campaign strongly focused on the rhetoric of drugs, crimes, corruption, and justice (law). Before that, he was a prosecutor, and has served as mayor of Davao for years, a city in the Southern Island of Mindanao, where he started a "crackdown on crime", and promised to take it to the national level, "to cleanse the country of drug users and dealers" by extrajudicial means (NEW YORK TIMES, 2016, p. n/a). In a dispute with 4 other candidates, he received around 16 million votes, nearly 39 percent, with his closest rivals trailing by more than six million votes (NEW YORK TIMES, 2016, p. n/a).

In an electoral campaign, it is important to say, the main goal of any discursive strategy is to persuade the electors in its favor and against other candidates, whereas electors want their demands to be implemented, and candidates to win the elections (FIGUEIREDO et al., 1997). Figueiredo et al. (1997) make an analytical distinction that may help: 1) scientific debates and their argumentative rhetoric; 2) political debates and their political argumentative rhetoric; 3) electoral debates and their fictional argumentative rhetoric. In the first one, speakers persuade the audience through logical deduction or demonstration of evidences, convincing them of the theory's truth. In the second, the idea is to persuade public audience about laws and policies, independently of logical or empirical truth. And in the third, the politico-electoral debates, candidates construct a "possible present world, equal or a bit different from the real current world, and based on it, project a new and good possible future world" (FIGUEIREDO et al., 1997, p. 186, my translation). The structure of this argumentation has two strands, they continue: "the world is ill, but it will get better" or "the world is great, and it will get even better. [...] The first strand is typical of the opposition's argumentation and the second of the situation's" [politicians] (FIGUEIREDO et al., 1997, p. 186, my translation). 


\section{NEIBA}

It is important to say here that Duterte followed the typical opposition's strand during the electoral campaign in which he addressed the debate on drugs and crimes - in a rather fictional way, according to Figueiredo et al. Fictional because

"the possible future good world didn't accomplish yet, and there is nothing in the logic, from which it is deduced, that guarantees its accomplishment; second, because the possible present world, be it great or ill, is a construct inferred from the real current world" (FIGUEIREDO et al., 1997, p. 186, my translation).

Accordingly, it can be said now that Duterte, in his electoral communicational strategy, resorted to a fictional inference from the (ill) current world, when arguing that drugs, crimes and corruption should be cleansed by extrajudicial means, promising to his audience a possible future world that, unfortunately, became real. In this sense, the transition from the (ill) current world to the (good) possible future world was made through the

"logic of interpretative inference of physical or social conditions in a given society, [...] typical of political argumentation and, especially, electoral campaigns, where the contextualization or interpretation of history, facts, and social conditions are the raw material for electoral discourse" (FIGUEIREDO et al., 1997, p. 186, my translation).

In a press conference on September 2016, already president in charge, Duterte made a polemic declaration:

"Hitler massacred 3 million Jews. Now, there [are] 3 million, what is it, 3 million drug addicts. I'd be happy to slaughter them. At least if Germany had Hitler, the Philippines would have, you know, my victims. I'd like to [kill] all criminals to finish the problem of my country and save the next generation from perdition" (CNN, 2016, p. n/a).

What is it, if not an interpretation of history, facts and social conditions that are strictly related to Duterte's political interpretative inference of the Philippines' drugs and criminal problem? Precisely, that is a political motivated interpretation that serves to legitimize, naturalize, or normalize in the political discourse (FOUCAULT, 1971), the potential genocidal practices of slaughtering criminals. Thus, when Duterte linkes himself to Hitler, he is not just comparing himself and his victims to those of Nazi Germany and its leader to emphasize his criminalization of drug related activities; he is situating his war-like antidrug political practices in a "zone of indistinction between legality and illegality" (ZACCONE, 2015, p. 144).

The polemic declaration rendered commentaries by the United Nations Special Advisor on the Prevention of Genocide, Adama Dieng, who "expressed alarm" at the public statements by President Duterte, "deeply disrespectful of the right to life of all human beings" (UNITED NATIONS, 2016, p. n/a). Mr. Dieng reminded that the Holocaust was "one of the darkest periods of the history of humankind and that any glorification of the cruel and criminal acts committed by those responsible was unacceptable and offensive" (UNITED NATIONS, 2016, p. $\mathrm{n} / \mathrm{a})$. He also called Duterte's attention for the need to restrain the use of language that could "exacerbate discrimination, hostility and violence and encourage the commission of criminal acts which, if widespread or systematic, could amount to crimes against humanity", and requested support in the investigation of the "reported rise of killings in the context of the anti-crime and anti-drug campaign targeting drug dealers and users to ascertain the circumstances of each death" (UNITED NATIONS, 2016). We 


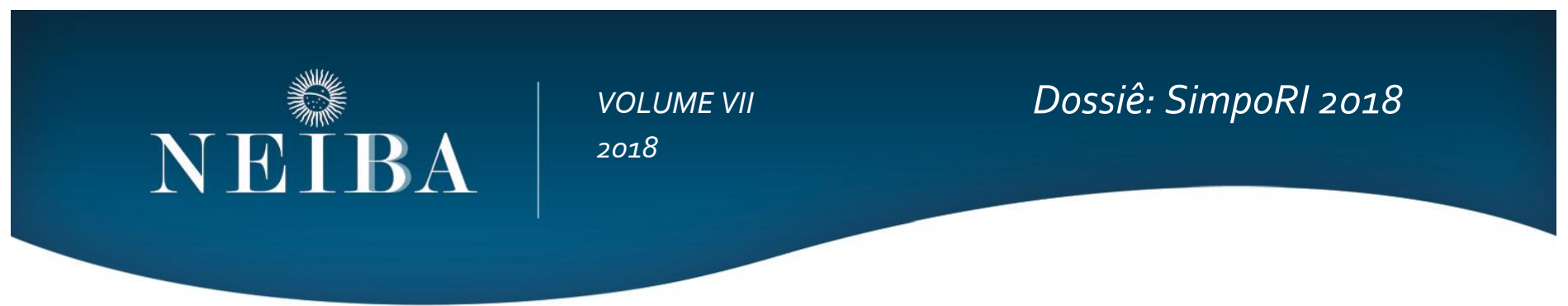

could think about performatives here, and Derrida's analysis of them.

A performative is a communication that "does not limit itself essentially in transporting a semantic content already constructed and watched by an object of truth" (DERRIDA, 1991, p. 363, my translation). In other words, through "instituted performatives" like the "war on drugs", or the "human rights", Duterte - and Dieng - consolidate an order, a 'state of fact', "the service of the 'strong' or, on the contrary, little by little, dismantle, put in crisis, menace" (DERRIDA, 2001, p. 52), as in the case of Dieng's mobilization of the concept of 'crimes against humanity', or even Duterte's own 'Mass Murder'. The war on drugs in the Philippines could be thought, thus, as "a 'performative' event of a scope still difficult to interpret" (DERRIDA, 2001, p. 29), since "[b]etween the two hypotheses, all depends on the politics that puts these concepts to work" (DERRIDA, 2001, p. 52). Nonetheless, the effects of this 'performative' event can, at least, be traced in journalist investigation.

Drug-related fatalities in the context of Duterte's war on drugs are reported since May 2016 by ABS-CBN, which started an independent monitoring of national and local news reports; Philippine National Police (PNP); Regional Office, and Philippines Drug Enforcement Agency's (PDEA) press releases. According to their charts and tables, in June 2016147 people were killed by the police and extralegal associations (what they call vigilantes), although the police killing could be classified as extralegal too. In July, one month after Duterte's election, the numbers grew spectacularly to 581, and held still: 558 in August and 569 in September, declining to 372 in October and to the lowest rate in the series, 64, in February 2017. The numbers oscillate during 2017, dropping down to 21 in November, 24 in December, and 22 in January 2018. In sum, during the first 78 days of Duterte's administration, the country has seen the highest rate of extrajudicial killings ever reported: more than 3,000 citizens have been killed 4 .

In October 2016, about 100 days in the presidency, Duterte answered questions on the "controversial war on drugs" in an exclusive interview5 for $\mathrm{Al}$ Jazeera, which started with questions on his "politically inclined family", on the fact that he was sexually abused by a priest, and how that affect his outlook and beliefs (AL JAZEERA, 2016). That is a very common way to start a conversation, to engage the interviewee - and the audience, to try to grasp his identity, his origins, and sell it. Interviews are addicted to that kind of "metaphysical language" (DERRIDA, 1997), its search for stability, an originary presence (i.e. familiar political background), and a rational sovereign subject who can talk about his traumas and beliefs. Derrida, and Foucault, in their common Nietzschean approach, however, reject this kind of language, this notion of a singular origin with a continuous line of descent that would legitimize inheritors of a true right or identity in contemporary power struggles, which are multiple and discontinuous.

From Rodrigo Duterte, president in charge, it was expected, I suppose, based on Figueiredo et al. (1997), that he acted like such, defending his political program, approved in the electoral process. Duterte has a commitment with his audience too: electors and citizens of his country, the international community, political opponents, and so on. When he makes an utterance, it is part of a rhetorical game addressing whoever that audience is. He might be answering the interviewer, but he is also talking (in)directly to those watching it on television or online broadcast transmissions.And the same is true for journalists, mayors, scholars, etc. It is important to keep that in mind for, when analyzing his statements, this article will be concerned not

\footnotetext{
${ }^{4}$ All data are available at: http://news.abs-cbn.com/specials/map-chartsthe-death-toll-of-the-war-on-drugs. Accessed on 01/20/2018.

${ }^{5}$ Part of the interview transcript was cut to fit in this article.
} 


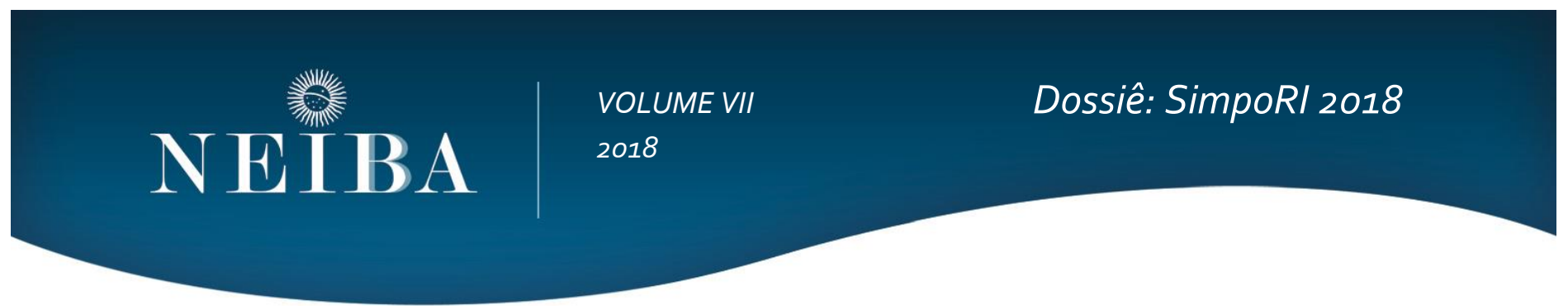

only with Duterte's identity, historical background and beliefs, or his capacity to interpret and react meaningfully to the questions directed to him, but also with his discursive strategies to persuade the audience to try to legitimize his war on drugs - including themilitarization of public security, the extrajudicial killing of thousands of 'drug'users, dealers, and innocentcitizens during a period of less than 3 months.

\section{The Political Rhetoric of "Drugs" and The Metaphor of "War"}

President Nixon is allegedly recognized for coining the metaphor of "war on drugs" 6 , but according to the historian Paul Gootenberg (2008), the expression dates back to the Second World War (1939-1945), when Nazi Germany was attacking coca-vessels coming to supply the Allied Forces, propagating, then, a discourse of war on drugs in a literal sense. There was a war going on, and part of the Nazi strategy in that war was concentrated on destroying the enemy's drugs vessels - mainly cocaine. In that sense, war on drugs[!] is an utterance, a performative, a speech act (AUSTIN, 1990, p. 28), or "a decree, a buzzword (mot d'ordre)" (DERRIDA, 1991, p.1).President Nixon's war on drugs, however, was too metaphorical (MIDDLEMASS, 2014), false in relation to its object (DERRIDA, 1997) - 'drugs', since it was, and it still is, not a war on drugs, but a war on people, specific subjects and parts of the population - poor, immigrants, criminalized and racialized 'others' (FOUCAULT, 2003; 2007; RODRIGUES, 2012).

On the one hand, drugs, a concept "instituted on the basis of moral or political evaluations", carryin itself both norm and prohibition (DERRIDA, 1991, p.1). On the other, the rhetorically effective category war has become central, because it promises a temporary state that will finish in the long run, "a powerful psychological promise that in both cases [the "War on Drugs" and the "War on Terror"] was crucial for mobilizing resources and popular support"

\footnotetext{
${ }^{6}$ See for example SCHMIDT, Dana, 1971; MIDDLEMASS, Keesha, 2014.
}

(LINTON, 2015, p. 80, my translation). As Linton has wisely written, although it can be fought and warred, the war on drugs cannot be won, neither finished, and it has brought important changes to global power relations: the United States has increased its military and juridical authority, intervening in countries like Colombia, Mexico, Afghanistan, in the name of national (and global) security (LINTON, 2015).

We could add here the U.S. annexation and subsequent war against the Philippines (1899-1902), also constructed in official discourse as 'counterinsurgency war', a paradigmatic policy that "construct[ed] identities and simultaneously positioned the subjects that were so constructed" (DOTY, 1996, p. 16). In other words, Philippines has increased its militarized security agencies authority - and encouraged paramilitary ones -to intervene (violently) in the drug economy in the name of "the law-abiding god-fearing young persons of this Republic", as Duterte saidin the interview (AL JAZEERA, 2016). And "we can note elements of continuity and discontinuity with earlier colonial discourses" (DOTY, 1996, p. 16) ${ }^{78}$. In that sense, drug addicts and dealers are constructed as others, as enemies to be fought and killed, because, in part, that is the colonized military logic informing the Philippine's reason of State, its rationality, its truth regime regarding militarized security policies against insurgents.

Drawing on Foucault's genealogy of the historicalpolitical discourse we could argue that although the war on drugs is not war in the western modern sense - "a trial by strength in which weapons are the final judges"; (professional) battles or combats; disruption of everyday life

\footnotetext{
${ }^{7}$ As Dotyputsit: Despite the United States' relative lack of experience with formal colonization as well as its ignorance regarding the Philippines and the Filipinos, it had ample experience with "others": blacks, Mexicans, and "Red Indians." This experience was drawn upon in coming to "know" the Filipinos and in justifying U.S. practices and policies. Significantly, the discourse instantiated in this imperial encounter exemplified the representational practices that were at work more globally in construction the West and its colonial-other(s) (DOTY, 1996, p. 28).

${ }^{8}$ On counterinsurgency, and 'war-police assemblages' see also BACHMANN, J., BELL, C. \& HOLMOVIST, C. (Eds.). (2015).
} 


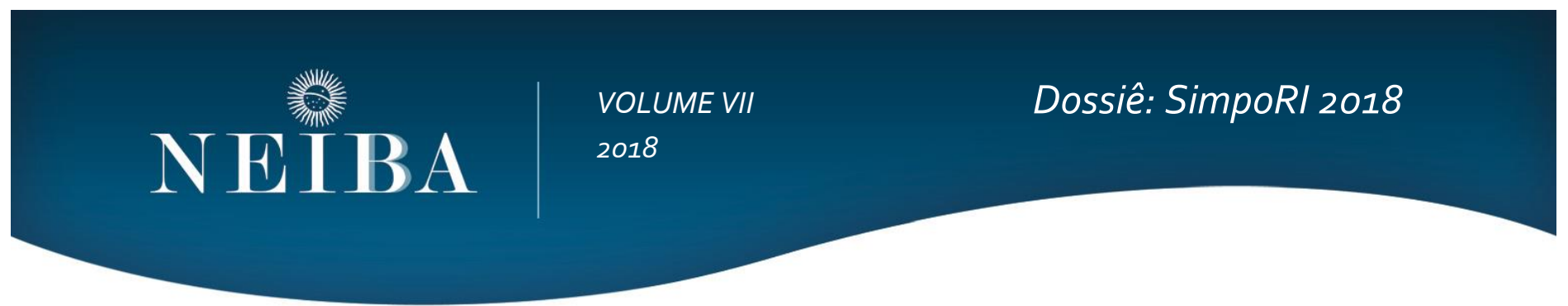

or "civil peace" - it is a sort of "silent war" that (re)inscribespower relations, as "warlike clash of forces", in "institutions, economic inequalities, language, and even the bodies of individuals" (FOUCAULT, 2003, p. 15-16), including public security (political) discourse(s) that aim at countering the invasionof barbarian others (FOUCAULT, 1971; 2003). Nonetheless, as one can see in the Philippines nowadays, we are discussing a kind of warlike politics of drugs that is not so silent, at least not for all Filipinos.

Different from Figueiredo et al. (1997), for Foucault, the political and scientific practices are more interwoven, in the sense that it is not reason in general that is implemented, but always a sort of specific rationality, reflexive, and conscious of its specificity (FOUCAULT, 2007). More precisely, this rationality was formulated in Western liberal democracies in two forms of doctrine: Raison d'État and Police Theory 9 . Following Foucault's argument that "the right is neither the truth nor the alibi of power. It is an instrument at the same time complex and partial of power", and putting light on the center of Benjamin's formulation - "the nexus between myth, violence, right and destiny", Orlando Zaccone rejects the jusnaturalist and positivist right's formulations, for they legitimize violence, be it by just ends or trough justified means (ZACCONE, 2015, p. 53-54; 64) - be it Nixon's "war on drugs"; W. Bush's "war on terror"; or Duterte's warlike drug politics.

Zacconeargues that "we cannot not observe that it is in a war-like style politics of drugs and "combat" against criminality that the State legitimizes the extermination of the enemy/criminal" (ZACCONE, 2015, p. 264, my translation). Coming from the historical level of mass-

\footnotetext{
9 The first tried to define how the principles and methods of government diverged from the way God ruled the world, father the family, or a superior the community, while the latter defined the nature of the objects of State's rational activities, the nature of its goals, the general shape of the instruments involved (FOUCAULT, 2007). It is important, thus, argues Foucault (2007), more than searching the State nature, situating the State in the process of development of power practices, in the history of "governmentality" (FOUCAULT, 2007).
}

incarceration in Brazil during the last two decades, and its relation to exterminating enemies/criminals, since he concludes that "the more you incarcerate, the more you kill" (ZACCONE, 2015, p. 265), Zaccone'snext quote will be relevant here for analyzing what is happening in the Philippines regarding the rhetoric of drugs in Duterte's political discursive strategies:

The so-called "war on drugs" comes to be an efficient recruiter of clients for the lethality of our penal system. It is not by coincidence "that the hegemonic criminal drug politics on the planet targets the global poor indiscriminately: be they young faveladosin Rio, peasants in Colombia, or unwanted immigrants in the North hemisphere". The drug traffickers come to constitute a "phantasmatic category", in the revealing expression of Vera Malaguti Batista, "a police category, that has migrated to the academy, journalism, psychology, and that is no longer human". Thus, the expression "war on drugs" sounds like a metaphor, for it hides, as any war, it is directed to hit people identified as enemies (ZACCONE, 2015, p. 139, my translation).

\section{"Mass Murder" in the Philippines, or, The Politics of 'Drugs', Crimes, and Justice (Law)}

The interview follows to the next issue: "the war on drugs" (AL JAZEERA, 2016). "3,500 people have been killed so far", continues one of the journalists, "it seems like the whole world is talking about that at the moment. The Philippines seems to have so many problems, so, why launch 


\section{NEIBA}

what is a brutal war on drugs?" (AL JAZEERA, 2016, 2'36" to $\left.2^{\prime} 52^{\prime \prime}\right)^{10}$

[R.D.]: "Because the sheer number of people contaminated will pull the country now, it will destroy the next generation of Filipinos. You know, these lives lost, some of them, were lost during legitimate encounters with the police" (2'53" to $\left.3^{\prime} 13^{\prime \prime}\right)$.

Firstly, drug use/addiction is not an infectious disease to be contagious. But Duterte's use of the expression reveals the roots of prohibitionism in medicinal discourses. Second, destruction - as an effect of drug use or addiction on the social bond - is used here as another metaphor of war that has the political strategic effect of legitimizing a public security dispositive, as well as exceptional, brutal, or extrajudicial measures, as "some of the [il]legitimate killings". In other words, drugs and the subjects associated with them need to be linked to an extreme threat (destruction) so their criminalization, incarceration, their death can be legitimized.

It could also be said that, since Duterte infers a possible future world (legitimate encounters with the police) from the ill current world (contamination), this is a fictional discursive strategy, with nothing in its logic that would guarantee its accomplishment (FIGUEIREDO et al., 1997). On the other hand, Foucault taught us about the pastoral power, and the role played bysalvation, that is, the submission of subjects into confession, a procedure of extracting the truth from them, and revealing it to them (FOUCAULT, 2007). In the Philippines, the police, the PDEA, and the vigilantes, beyond physical and mortal violence, also enforce a certain pastoral power when, authorized by Duterte's (extra)juridical-(bio)political discourse, make searches, stop passengers on the streets, break into houses, or force a

${ }^{10}$ From here on I will be using "[A. J.]" for Al Jazeera Journalist and "[R. D.]" for Rodrigo Duterte. confession of crimes. Then it is not only about the 'subject', but also subjectivities and processes of subjectivation.

[A. J.]: "But the fact is, at the moment we have 3,500 people killed and you yourself alluded to, just then, that, perhaps, some of them weren't legitimate targets" ( $3^{\prime} 14^{\prime \prime}$ to $\left.3^{\prime} 24^{\prime \prime}\right)$. That is, Duterte didn't deny the illegitimacy of those killings, but his moral claims were supposedly enough for legitimizing some of the lives lost. What about the lives lost in illegitimate encounters with the police? Or the innocent lives lost in "legitimate" ones? That remained an open question.

[R. D.]: "You know, there is no crime at all when you threaten criminals with death. In my country at least there is no law which says I cannot threaten criminals, and that was the favorite [...] of course the cliché that they used, that became a cliché over time. And then I was president and I said: we have three million, according to PDEA, three million drug addicts, not counting [...], because it is still going on. So I said: if we do not interdict this problem, the next generation will be having a serious problem. And I found, again, the same, you destroy my country, I kill you! And it is a legitimate thing. If you destroy our young children, I will kill you! That is a very correct statement. There is nothing wrong in trying to preserve the interest of the next generation. That three million addicts [...] are not residents of one compact area or contiguous place. They are spread all over the country. And by the sheer number, because if you are a user, you must push! Unless you are the son of [...] a millionaire, or $[. .$.$] because you have to$ sustain your addiction by getting another financer for you, and then the next financer will have to get a new victim to finance it. 


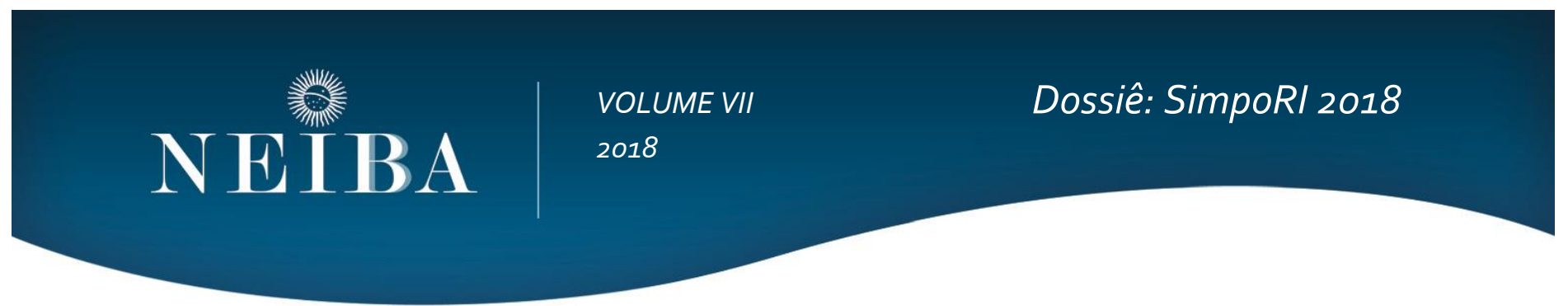

That's how drugs are spread. But it was not until I became president, that the widespread and the magnitude of the problem became really a serious issue (3'25" to $5^{\prime} 25^{\prime \prime}$, emphasis added).

It is shocking to see how naturally he talks about killing. This could be said to be a discursive strategy, chosen precisely to generate power and knowledge effects in part of the population, that is, to send a message, to produce fear, to advise on the possible consequences of breaking the law, and to reinforce a security rhetoric on drugs. But it is not about making life live, it is about killing life. Second, he didn't answer the question, which was on the illegitimate, or extrajudicial killings, rather, he talked about drug addiction, which is not a crime - although drug use is criminalized. One can't, or at least shouldn't be considered a criminal for being in that condition. Duterte, however, likens drug addition to criminality and argues it is legitimate and correct "to threaten criminals with death", which is untrue, since the death penalty was banned from the constitution in $2006^{11}$.

Even if drug addiction was a crime, the Philippines State has no right to kill its own citizens in the name of society's safety. In any democracy where the due legal process is respected, people have the right to access the juridical system, to face a trial, to be judged, and if convicted, punished in accordance with the penal code. In other words, once he defines drug dealers and users as threats to the society, to the "next generations", an enemy in the first place, the possible actions are reduced to elimination, exclusion, or segregation. Instead of criminal, drug addiction could be described as a health condition. The effect of such a medicinal statement would be the logical (and political) demand of public resources for Health, not Security

\footnotetext{
${ }^{11}$ Available at: http://www.philstar.com/opinion/70640/death-penaltyabolition-reinstatement-abolition. Accessed on 20/01/2018.
}

Agencies, which apparently is in contradiction with Duterte's electoral promises and political goals.

Third, again, we can see how the process of veridiction over criminalized subjectivities reproduces power relations. All the electoral-political discourses on medicine, law, criminology, economics, history, and security (re)produces a power- and truth-effect. It establishes a truth regime, a set of institutions, practices, rules, and norms to represent the Philippines' citizens, and/or to exclude the nonfull citizens, the 'others', the enemies, to secure 'us' from 'them'.

Fourth, Duterte uses the metaphor of 'destruction' again, inflating the consequences of drug use. "If we do not interdict this problem, the next generation will be having a serious problem", he says, which is true, but there are many ways of interdicting a social (health) problem. He links "destruction" to "young children", a category automatically related to vulnerability, in a discursive strategy that aims at stimulating fear and legitimating violent anti-drugs measures.

Fifth, through this rhetoric game, he is also addressing those who are involved in criminal activities, making as clear as possible that he "will kill you". How do we make sense of such a statement? Following Figueiredo et al. (1997), this is a fictionaldiscursive strategy and a logical (and political) contradiction, since a significant part of the next generation is not being preserved, but quite the contrary, it is being slowly killed, and will be constituted by orphans and traumatized and stigmatized children.

Finally, he categorizes the drug addicts as "victims", no longer the rational sovereign subject of crimes, investing them with evaluative meaning, that is, passive agents or objects of drugs. But if sheis a "victim", why not treat her like that? Why not give her health treatment, juridical assistance, job opportunities, and so forth? "That's how drugs are spread", he says, but is that so? What about supply and 


\section{NEIBA}

demand? Where do the most consumed drugs in the Philippines come from? How do they enter the territory? How are they distributed? Is it possible to deal drugs in a prohibitionist countrywithout the help of law enforcement agents? In sum: there is no drug trafficking without corruption, and that is, perhaps, why Duterte emphasized a crackdown not only on drugs, but corruption and criminality more generally during his electoral campaign. The problem is not the end, but the political means to accomplishit.

Therefore, what is happening in the Philippines is not war, but the securitization of a public health issue (drug addiction) and the militarization of public security, that is, the "expansion of the criminal justice apparatus to intensify unprecedentedly harsh punitive sanctions and coercive practices, with attendant collateral damage, especially in urban centers and against socioeconomically excluded populations" (CORVA, 2009, p. 164-165). In other words, the actualization of the (bio)political security dispositive to discipline, punish, control, repress, and in the limit, to kill specific populations of the nation (FOUCAULT, 2003; 2007). The point here is how life as truth and objective can be reconciled with death/killing. As Foucault showed in Security, Territory, Population, the emphasis has changed from the 'subject' to the 'species' throughout several knowledge practices (savoir-faire), especially biology, medicine, psychiatry, political theories, and the links among them.

The journalists insisted on the question of children and innocent people killed, but Duterte did not properly answer again. He gave an interesting example, however, of what he called "legitimate encounters with the police", where he places all the responsibility for the "missing bullets" that supposedly hit "one thousand people" - an hyperbolic expression that helps him to inflate his weak (political) argumentation -among them "innocent children", on the police, because they are equipped with better guns ( $\mathrm{M}_{16 \mathrm{~s}}$ ) (AL JAZEERA, 2016).
He also admits corruption in theState justice system, which makes the economy of punishment to fail, that is, disciplinary, regulatory and security mechanisms are negative in relation to the supply of crimes (FOUCAULT, 2007). On the other hand, he "should believe in the system because he will guarantee that the law is obeyed" [emphasis added], and not because he is a lawyer, a prosecutor, a mayor, and the president of the Republic of Philippines and truly believes the system of justice (law). That is, again, a political argumentation which infers a future possible world from the current (ill) world (FIGUEIREDO et al., 1997).

[A. J.]: "But do you agree, do you acknowledge that you have encouraged vigilante killings?" (7'42" to $\left.7^{\prime} 45^{\prime \prime}\right)$.

[R. D.]: "No, I said I will kill you! If I encourage, fine!" ( $7^{\prime} 46^{\prime \prime}$ to $\left.7^{\prime} 48^{\prime \prime}\right)$.

[A. J.]: "Yes, but the point is that people can get away with murder right now and you know that some of the killings are not legitimate. So, do you think that might be cases of people settling old scores out there and disguising them as the war on drugs?" ( $7^{\prime} 46^{\prime \prime}$ to $\left.8^{\prime} \mathrm{O}^{\prime \prime}\right)$. That is a central question in the "war on drugs" debate: impunity for 'white collar' crimes/criminals. If the president himself guarantees that you can go out on the streets and kill drug users/dealers - in fact he is the role model for that kind of behavior -, without facing the consequences of a criminal investigation, then, why wouldn't you do it?

[R. D.]: "I do not play with conjectures. I do not make assumptions. I just say what I should be saying as a President under [...]. Now, if the criminals are killed by the thousands, that's not my problem. My 


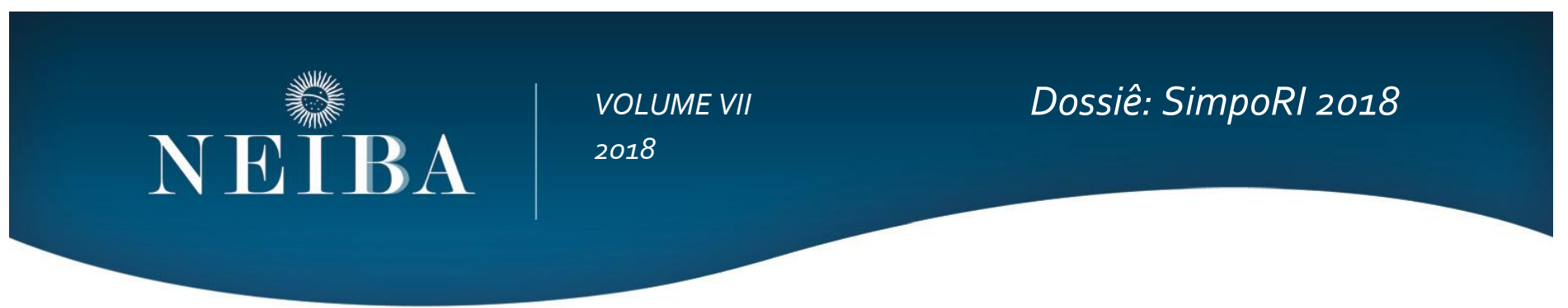

problem is how to take care of the lawabiding god-fearing young persons of this Republic, because they are resources. Strictly speaking, you cannot find any redeeming factor in being, you know, the criminals there. They are there for what? They are there just like the cartel in Mexico. If you read lan [last name], this is how the cookie crumbles. Exactly! So, [...] I will kill you, because I am the mayor, I am the president. Now, if the vigilantes take over, I cannot control it. I cannot be god and control everything. Okay, you just kill these guys, or you just wait for the courts to do that ( $8^{\prime} 03^{\prime \prime}$ to $9^{\prime} 11$ ', emphasis in the original).

So whose problem is it? When the president himself has already declared that he has killed; that those people deserve to be killed; that it is legitimate by the law; now that he has enforced that kind of drug politics, the problem is definitely his. Second, Duterte uses "to take care" here, in his rhetoric on crimes; punishment; security, in a "logocentric binary opposition" (DERRIDA, 1997) to killing, both as possible public security (and health) policies, but an hierarchical opposition that privileges the first term, "to take care", discursively constructed as a right only for the "lawabiding god-fearing young persons of this Republic, because they are resources". That is a political discourse that represents the rationalities behind the modern State reason: preservation and expansion of political power, discipline, regulation and security for the sovereign population (FOUCAULT, 2007).

Duterte's discourse, reliant on the metaphor of war, and informed by the language of logocentric metaphysics, and state reason, "criminals", especially drug users/dealers, are constructed as the Philippine's homo sacer, that is, the bodies which hold the 'violence/law' nexus, in opposition to the civilized/citizens (e.g. the "law-abiding god-fearing young persons of this Republic"), "being the idealization of the social contract the object which guarantees the passage from one side to the other" (AGAMBEM, 2009 apud ZACCONE, 2015, p. 124, my translation).

[A. J.]: "Sir, in the past, during your campaign, and weeks into your presidency you have repeatedly said you have no regard for human rights, but human rights is actually part of the constitution, and as head of the State, it is also part of your duty to uphold the constitution. How does that connect?(11'07" to 11'24").

[R. D.]: "I would rather intimidate and strike fear in the hearts of the criminals just like what happened in Davao, when finally you can walk the streets, walk about in the streets at night and you can eat anywhere at any time and nobody would bother you. It's happening in Davao. Davao city is in the midst of Mindanao in [...] but 1 can assure you as plenty of people have been there, it's a destination for conventions and conferences international. [...] It's booming. It is a little bit richer than the others. Why? Because we can live our lives normally, and, of course, business [...]. So, that when I said I do not care about what the human rights guys say, I have a duty to preserve the generation. If it involves human rights, I don't give a shit! I have to strike fear, because I have, I said, the enemies of the state are out there to destroy the children" (11'25" to $\left.12^{\prime} 48^{\prime \prime}\right)$. 


\section{NEIBA}

Thus, the "connection" he is suggesting is: even if his actions against criminality, especially drug use and dealing, represent a violation of human rights, it does not matter, because his goal is to provide security for(part of) the population - and for the market. This is a question of political priorities. He promised to deliver a "war on drugs" and that is what he is doing, no matter what. But what if the means to combat criminality are criminal? Violation of human rights are crimes against humanity, and are predicted in the constitution, as the journalist reminded him, a situation that sounds the alarm for preventing those crimes, including genocide, hence UN Special Advisor on the Prevention of Genocide, AdamaDieng's statement.How could the population feel safer on the streets when there is an official politics that stimulates vigilantehunting and killing of criminals? If that increasesfear in part of the population, it does not mean security but insecurity.

Second, Duterte makes use of the expression "strike fear" twice in this part ofthe interview:1) it is used as a synonym with intimidation, when he is referring to the "criminals". He wants "to strike fear in the heart of the criminals", he wants to intimidate them, to increase the feelings of fear; 2) it is used in the opposite direction: he wants to strike fear, to eliminate it, to decrease it.

Third, and related - to the extent that his statements are deeply ambiguous - he uses, once again, the word "destroy" associated with "children", and "criminals"associated with "the enemies of the State", which, in accordance withhis militarized and Statistdiscourse narrowsdown future possible political actions regarding drugs, security, and public health to a war-like style of politics of drugs, and "combat" against criminality(FOUCAULT, 2003; ZACCONE, 2015).

[A. J.]: "Aren't you worried about possible ramifications in the future for you, a possible impeachment or being tried in the international court?" (12'49" to 12'56").
[R. D.]: "Good question" [with a smile in his face]. Before you can begin, you must determine that I have committed a crime in my country, that I have committed massmurders in my country and then charge me there. There can be no ramifications when I say that I will kill you if you destroy my land. It is a legitimate [...] statement of any general, of any wartime president, of any tribal leader to say those things. Of course, you said there can be consequences, but I am not worried about this thing, I do not make any projections. How many vigilante killings? Well, if you compare the four million to the three thousand minus legitimate encounters between the law enforcement and the criminals, give or take even a half of it, so, what is it to the lives already lost? I have four million addicts to take care of. And I have been criticized, I would say, well, "why don't just, you know, Duterte, build rehab centers and just place them there. Why do you have to kill them?" Look, I am a midterm president, in the sense that I entered this year the presidency, only this year. The budget of this year was prepared by my predecessor, Sir Aquino, and it binds me because it will last until December. Nowhere in this budget provides enough money to build even two buildings or rehab structures. It is all that is left for my government now, after the election. It is just enough for the M.A.O., Maintenance and Order. No capital outlays" (12'57" to 15'09").

Nobody mentioned the expression "mass murder" and he suddenly defends himself from it, which means that somehow, he is aware that this crime has been 


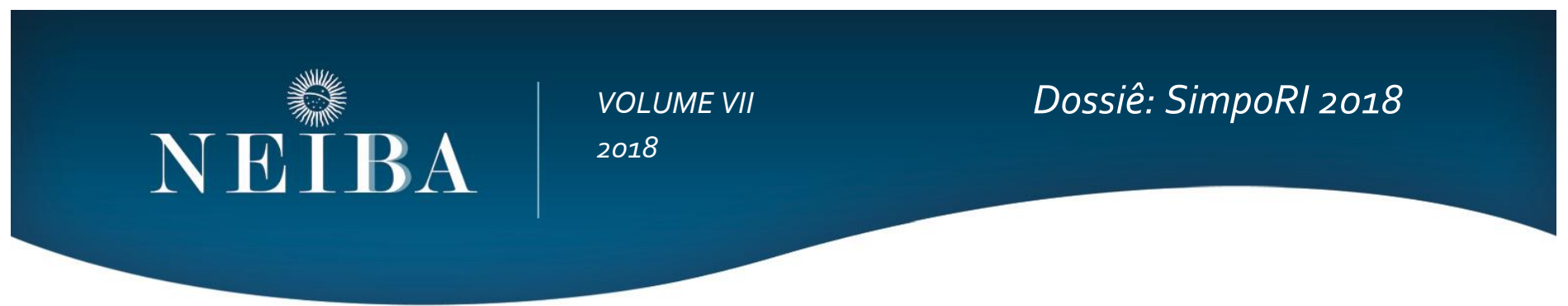

committed. He is playing legitimacy again with this issue of "I told you so"; "if I told you in advance you cannot complain now". He says he does not have the money, but the fact is he just not willing to build rehabilitation centers.Upgrading health is not his primary concern because he is in charge of a sovereign power of life and death, which also constitutes his own subjectivity.

It should be said that, up to this point, they haven't made explicit which drugs they were talking about. On which drugs are Filipinos addicted to? That remained an open question. Where does it come from? Apparently it comes from China, when the journalist touches this point, later in the interview, talking about Philippine-Chinese relations, but he doesn't show any interest in talking about alternatives for drugprohibition; health policies for addicted young "persons of this Republic"; about being "tough on crime" and corruption (i.e. military and police agencies that are accessary with "drug lords"). And if we don't know which drugs we are talking about, its effects in the (social) body, then, how to prevent addiction, public (in)securities and health issues? How to formulate specific, economically viable policies? What about licit drugs? Are people addicted to them? Is he going to kill them too? I don't think so. Perhaps those are the millionaires' drugs. Nonetheless, his last point makes sense. It really is a problem for anyoneconcerned about decriminalizing medicinal marijuana ${ }^{12}$ - and other medicinal plants -how to set the rules/norms for this process,protecting the rights of those who need this medicine the most; those who cultivate, or use them therapeutically and religiously. In effect, how to protect the

\footnotetext{
12 It is curious, if not paradoxical, to know that Duterte is in favour of medicinal marijuana decriminalization, as he has already made public. For example, see Al Jazeera's short article on the subject matter, "Medical Marijuana Amid Duterte's Drug War", available at: https://www.aljazeera.com/indepth/features/2017/06/fighting-medicalmarijuana-duterte-drug-war-170604070616008.html. Accessed on 25/01/2018. For an introduction to the Medical Uses of Cannabis, see also https://www.learngreenflower.com/articles/574/medical-uses-of-cannabis. Accessed on 01/25/2018.
}

rights of those with no rights in Duterte's declared "war on drugs"? ${ }^{13}$

\section{Closing Remarks}

Although the "war on drugs" is a metaphor mobilized within a discursive strategy prior to, during, and after presidential elections - the rhetoric of drugs, crimes, and justice - which attempts to maintain a set of power relations and positions (i.e. criminals; law; police; the PDEA; vigilantes; presidency, etc.) within the political system of the Philippines, it is also a national security policy based on confrontations and, in the limit, extermination, of declared enemies/criminals (drug users/dealers).

Through the symbolic language of war, President Duterte admits and legitimizes exceptional violent measures to deal with the problem of violence, crimes and (in)security. $\mathrm{He}$ also categorizes people according to their activities, as an effect of prohibition and criminalization of such activities (drug use; production; distribution; sell, etc.). And this categorization could be analyzed, for example, in relation to the stigma produced in people's lives, be they self-identified to such categories (user; addict; dealer; criminal) or institutionally "subjectified"14 (FOUCAULT, 2007, p. 239).

If we are to struggle against disciplinary power, "in our search for a non-disciplinary power, we should not be turning to the old right of sovereignty; we should be looking for a new right that is both anti-disciplinary and emancipated from the principle of sovereignty" (FOUCAULT, 2003, p. 40, emphasis added). Foucault did not want to get away with

13 The interview continues, on issues that don't matter for the moment, but for those interested it talks about relations with China, the US, and the UN.

\footnotetext{
${ }^{14}$ Foucault was concerned here with the problem of the subject, a specific modern Western subject constituted by pastoral and political power (governmentality), " a subject whose merits are analytically identified, who is subjected in continuous networks of obedience, and who is subjectified through the compulsory extraction of truth" (FOUCAULT, 2007, p.239-240).
}

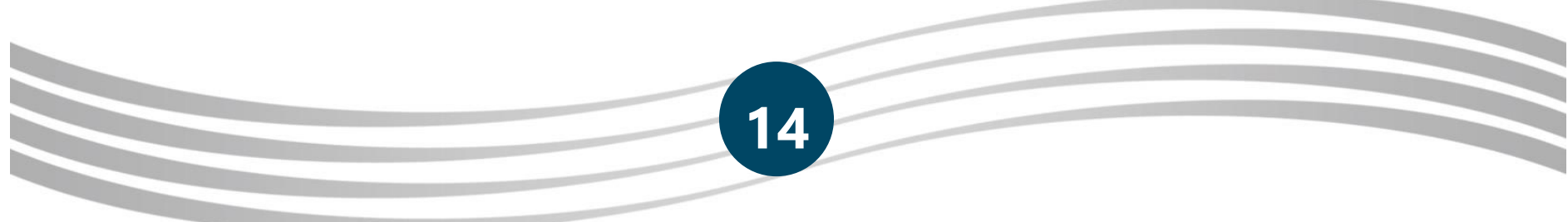




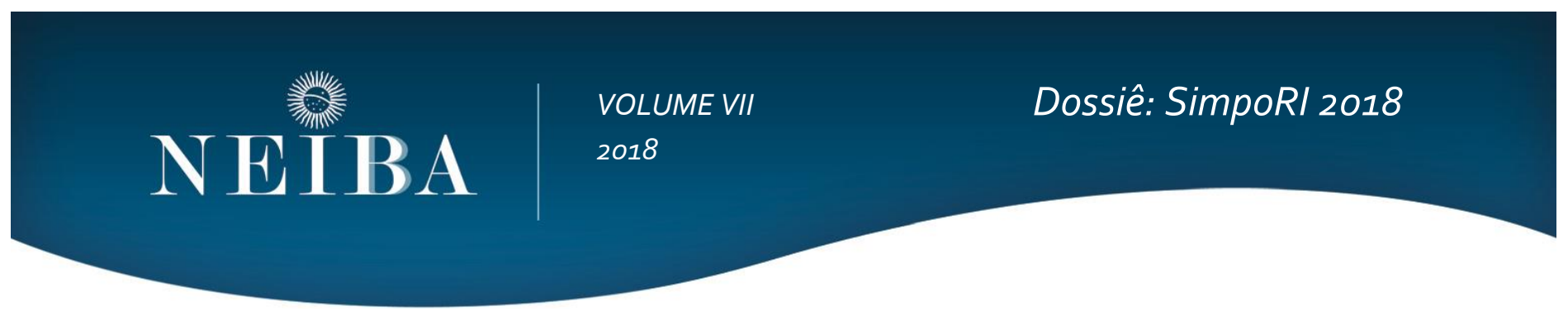

power at once and for all in his analysis of modernity, but to search for non-disciplinary, non-biopolitical power relationsamong (political) forces, subjects, institutions and a non-sovereign, non-formal, non-bourgeois public right.

All this discussion on political violence and public right will be important to know which direction, how much of State and market intervention, and how far could go the public debate on drugs decriminalization, legalization, or regulation, especially medicinal marijuana, and other alternative uses of drugs. Those are discourses heavily reliant upon the (metaphysic) language of law, which is also fundamental for prohibitionist discourses; that's why Derrida (1991) wanted not only to reverse the binary opposition (prohibition/legalization), but to displace the very epistemological foundation of that language, calling attention to the literary experience, or the search for truth, as also asupplementary experience, a sort of play in the world, which might involve hallucinogenic, toxic, relaxing, stimulating, substances, be they smoked, drank, introduced, expelled.

Here the point is: legalization discourses are starting to build a consensus around the fact that selective prohibitionist mechanisms and apparatuses have violated rights - human rights; civil rights; constitutional rights -, which, in the Philippines, could be related to the extrajudicial killing of more than 3, 500 people during the first months of a "midterm" presidency, although the total number of people killed in Duterte's declared war on drugs is difficult to estimate, varying from 7,000 to 21,000 .

In addition, "we should question this paradoxes of modernization in the criminal justice systems which establish the solution to urban violence within punishment", wrote Orlando Zaccone, who alsoargued "we can only effectively question the Police State's violence within the structure of the State of Law if we position ourselves against punitive power in all its plenitude" (ZACCONE, 2015, p. 262, my translation). In other words, decriminalization of medicinal marijuana may be an alternative for now, or a "good possible future" in any electoral and/or political rhetoric that addresses the theme of drugs (FIGUEIREDO et al., 1997; DERRIDA, 1991), but the horizon that should guide our discursive strategies in the public debate on drugs, crimes, (racist) criminal justice systems, punishment, mass incarceration, extrajudicial killings or "mass murder", is penal abolitionism. 


\section{NEIBA}

VOLUME VII

Dossiê: SimpoRI 2018

2018

\section{BIBLIOGRAFIA}

AL JAZEERA. Rodrigo Duterte on Drugs, Death and Diplomacy: Talk to Al Jazeera. YouTube: Al Jazeera English, 2016. Available at: https://www.youtube.com/watch?v=S2KtLTXXej8. Accessed on 20/01/2018.

BACHMANN, J., BELL, C. \& HOLMOVIST, C. (Eds.). War, police and assemblages of intervention. London: Routledge, 2015.

BATISTA, V. O Alemão é muitomaiscomplexo: Textoapresentado no 170 Semináriolnternacional de CiênciasCriminais, São Paulo, 2011. Disponivelem< http://gajop.org.br/justicacidada/wp-content/uploads/O-Alemão-é-muito-mais-complexo.pdfs.Acessoem 23 jun. 2016.

BREEN, M. D. Exploring Australian journalism discursive practices in reporting rape: The pitiful predator and the silent victim. Discourse \& Communication, v.11, n. 3, 2017.

CORVA, D. Biopower and the Militarization of the Police Function. Washington: ACME, 2009.

CNN. Philippines President likens himself to Hitler, 2016. Available at: http://edition.cnn.com/2016/og/30/asia/duterte-hitlercomparison/index.html. Accessed on 01/20/2018.

DERRIDA, J. Of Grammatology. Baltimore: The John Hopkins University Press, 1997.

Margens da Filosofia. Campinas: Papirus, 1991. p. 349-370.

On Cosmopolitanism and Forgiveness. London: Routledge, 2001.

The Rhetoric of Drugs: An Interview. Autrement, n. 106, translated by Michael Israel, 1991 [1989].

DOTY, R. Imperial Encounters: The Politics of Representation in North-South Relations. Minneapolis: University of Minnesota Press, 1996.

FIGUEIREDO, M.; ALDÉ, A.; DIAS, H.; JORGE, V. Estratégias de persuasão eleitoral: uma proposta metodológica para o estudo da propaganda eleitoral. Opinião Pública, n.4, v.3, p.182-203, 1997.

FOUCAULT, M. AArqueologia do Saber. Petrópolis: Ed. Vozes, 1971.

Society Must Be Defended: Lectures at the Collège de France, 1975-76. New York, Picador, 2003.

Security, Territory, Population: Lectures at the Collège de France, 1977-1978. London: Palgrave Macmillan, 2007.

Aesthetics, MethodandEpistemology. Edited by James Faubion. Translatedby Robert Hurleyetal. New York: The New York Press, 1994.

GOOTENBERG, P. AndeanCocaine: TheMakingof a Global Drug. Chapel Hill: UniversityofNorth Carolina Press, 2008. p. 189-241. 


\section{NEIBA}

VOLUME VII

Dossiê: SimpoRI 2018

2018

JULIOS-COSTA, M. The age of crime: A cognitive-linguistic critical discourse study of media representations and semantic framings of youth offenders in the Uruguayan media. Discourse\& Communication, v. 11, n. 4, 2015;

LINTON, Magnus. La guerra contra lasdrogas: de Richard Nixon a Barack Obama. Revista Nueva Sociedad, n. 255, p. 69-80, 2015.

MIDDLEMASS, K. War as Metaphor. In: FARMBRY, K. (Ed.). The War on Poverty: A Retrospective. New York: Lexington Books, 2014.

NEW YORK TIMES.Philippine's new president, Rodrigo Duterte, vows tough stance on crime, 2016. Available at:

https://www.nytimes.com/2016/07/01/world/asia/philippines-duterte.html. Accessedon 01/20/2018.

RODRIGUES, T. Narcotráfico e Militarização nas Américas: Vicio de Guerra. RevistaContextolnternacional, vol. 34, n. 1, p. o9-41, 2012.

SCHMIDT, Dana. "PresidentOrdersWiderDrugFight; Asks \$155 Million." New York Times, June 18, 1971.

SCOTT, J. DeconstructingEquality-versus-Difference: Or, The Uses ofPoststructuralistTheory for Feminism. FeministStudies, vol. 14, n.1, 1988, pp. 32-50.

SCHRIFT, A. Twentieth-Century French Philosophy: key themes and thinkers. Malden: Blackwell Publishing, 2006.

SHERRATT, Y. Continental Philosophy of Social Science. Hermeneutics, Genealogy, Critical Theory. New York: Cambridge University Press, 2005.

STROM, M.; ALCOCK, E. Floods, waves, and surges: the representation of Latin@ immigrant children in the United States mainstream media. Critical Discourse Studies, v. 14, n. 4, 2017.

UNITED NATIONS. UN adviser on preventing genocide alarmed over 'disrespectful' comments by Philippines president, 2016.Available at http://www.un.org/apps/news/story.asp?News/D=55180\#.WnN5pa3Orwe. Accessedon 01/02/2018.

ZACCONE, O. Indignos de Vida: A forma jurídica da política de extermínio de inimigosnacidade do Rio de Janeiro. Rio de Janeiro: EditoraRevan, 2015. 